\title{
Life's Crucial Transition \& Leads for Comprehensive Trajectory: Adolescents survey at physiological stages for prudent policies and refinements for practice
}

\section{Sunil Jain ( $\nabla$ sunil_jain700@rediff.com )}

Command Hospital (NC) https://orcid.org/0000-0002-3935-9243

Abhishek Mallick

Command Hospital (CC)

Rajeev Kumar Thapar

Command Hospital (CC)

\section{Research article}

Keywords: Adolescents, Behaviors, Diet, Mental health, Physical activity

Posted Date: June 25th, 2019

DOl: https://doi.org/10.21203/rs.2.10661/v1

License: (c) (1) This work is licensed under a Creative Commons Attribution 4.0 International License. Read Full License

Version of Record: A version of this preprint was published at Journal of Family Medicine and Primary Care on January 1st, 2020. See the published version at https://doi.org/10.4103/jfmpc.jfmpc_339_20. 


\section{Abstract}

Background Adolescent health information within new global health initiatives is advocated. Global School-based Student Health Survey (GSHS) is among young people aged 13 to17 years. Early preventive and health promotion actions can be beneficial. With the objective of finding out the current health behaviors and protective factors at different physiological stages of adolescence this study was carried out. Methods School-based survey using self-administered questionnaire of adolescents studying in an Army Public School. The study parameters were Dietary behaviours, Hygienic practices, Mental health, Physical activity, and Protective factors. A total of 1232 adolescents were surveyed. Early adolescence (10-13years) participants were 760 and middle adolescence (14-17 years) were 472. Overall male: female ratio was 1.819: 1. Results The study findings reveal interesting trends. There is disparity between BMI findings and effort direction for weight. There is a sharp rise in number of girls making efforts to lose weight from early adolescence to middle adolescence (27.8\% and $40.7 \%$ respectively). Hygienic practices are marginally short of $100 \%$. Worry causing inability to sleep at night most of the times or always is reported by $9.2 \%-18.7 \%$. There is sharp rise in number of girls feeling this from early to middle adolescence ( $9.8 \%$ to $18.7 \%$ ). Adolescents spending three or more hours per day doing sitting activities are $25.6 \%-38.6 \%$. This is rising from early to middle adolescence, and sharply in girls. Protective factors are trending towards positive side. Conclusions Firstly accomplishing the advancements of adolescents' health, the top priorities are (i) Popularizing the importance of ideal BMI (ii) Betterment of mental health for smooth transition across different stages of adolescence \& being proactive for preventing worsening (iii) Promoting physical activity early \& sustaining efforts, especially amongst adolescent girls. Secondly the 'GSHS Questionnaire' needs to be modified for fruits \& vegetable consumption to how many servings/what part of plate and should include questions for details of physical activity likings of the girls.

\section{Background}

Adolescence is period of transition \& change. Opportunities for prevention and early clinical intervention for smooth transition with tactful strategies are immense. The development of health information systems to support this work has been weak and so far lagged behind those for early childhood and adulthood [1]. A study of adolescents' current trends at progressive physiological stages should have important implications.

With the aim to find the health behaviors and protective factors among adolescents, and for correlation, comparison, \& advancements vis-a-vis Global School-based Student Health Survey (GSHS), this study was planned \& carried out [2].

At present, there is no internationally agreed set of indicators for adolescent health [1]. Patton et al carried out a synthesis of internationally comparable data, and the indicators incorporated elements from earlier national reports including measures of health and wellbeing, social role transitions, risk and protective factors, and health service system responses. More recently, as per World Health Organization 
(WHO) main health issues for adolescents are (i) Early pregnancy and childbirth (ii) Human Immunodeficiency Virus (iii) Other infectious diseases (iv) Mental health (v) Violence (vi) Alcohol \& drugs (vii) Injuries (viii) Malnutrition and obesity (ix) Exercise \& nutrition (x) Tobacco use (xi) Rights of adolescents [3]. However on the basis of our experience of day-to-day clinical practice of more than two decades, we focused on Dietary behaviors, Hygiene, Mental health, Physical activity, and Protective factors.

\section{Methods}

\section{Study design}

School-based survey using a self-administered questionnaire to obtain data on young people's health behaviors and protective factors.

The WHO GSHS Questionnaire based survey methodology [4] used with the following modifications (i) The participant's modification- The GSHS is conducted primarily among students aged 13-17 years. However, all adolescents of 10 years and above were included in the present study with following reasoning: Firstly adolescence period of development is divided into 3 phases - early (10-13 years), middle (14-17 years), and late adolescence (18-21 years), each marked by a characteristic set of biologic, cognitive, and psychosocial milestones [5]. Secondly early action at an early age should be fruitful. (ii) The Core Questionnaire Modules modifications- part of the '2006 India, Central Board of Secondary Education (CBSE) GSHS Questionnaire' was used, the most clinically relevant ones. These were Dietary behaviors, Hygiene, Mental health, Physical activity, and Protective factors.

\section{Participants}

Adolescents studying in an Army Public School (APS).

\section{Sample size}

The results of the 2007 India (CBSE) GSHS vary from $2.6 \%$ to $45.6 \%$ of adolescents for the Dietary behaviors and overweight, Hygiene, Mental health, Physical activity, and Protective factors [6]. Taking the average of this $(24.1 \%)$, the sample size calculated was 1260 at an allowable error of $10 \%$. Hence 1260 adolescents were studied.

\section{Sample selection}


The participants were from the school classes VI to XII. The classes were randomly selected and all students in selected classes were eligible to participate.

\section{Administration}

Survey administrators and coordinators instructed and explained to the student participants the following (i) This survey is about your health and the things you do that may affect your health. The information you give will be used to develop better health programs for young people like yourself. (ii) Do not write your name. The answers you give will be kept confidential. (iii) Answer the questions based on what you really know or do. There are no right or wrong answers. (iv) Completing the survey is voluntary. Your grade or mark in class will not be affected whether or not you answer the questions. If you do not want to answer a question, just leave it blank. (v) Make sure to read every question. Tick mark the answer you feel is the most appropriate according to you \& for you.

\section{Data compilation \& analysis}

This was done including the following data edits (i) Out of range edits: none in the present survey (ii) Multiple Response Edits: if a student selected more than one response for a question, then the question was set to missing for that student (iii) Logical Consistency Edits: none in the present survey (iv) Height, Weight, and Body Mass Index (BMI) Edits: Weight and height measurement is regularly done in APS. The students entered the last measurements. Height and weight were used to calculate body mass index (BMI). Height, weight, and $B M /$ were edited to ensure that results are plausible before the indicators for underweight, overweight, and obesity are calculated. Biologically Implausible Value Editing was also done. These were none in the present survey. (v) Variable-Level Edits: none in the present survey (vi) Record-Level Edits: Data were checked to ensure that each student had at least $1 / 3$ valid responses once all other edits had been completed. Data were also checked to ensure that there are no cases of too many of the same response successively. Based on these 28 student records were deleted.

If the student did not enter response or multiple responses were entered to a particular question, the percentage result for the question was calculated from the total number of valid responses.

Nutritional status was defined as per BMI for age: (i) overweight $>1$ standard deviation (SD) (ii) obesity $>2$ SDs (iii) Underweight $<2$ SDs of the WHO Growth Reference median for age \& sex [7].

\section{Results}

A total of 1232 adolescents' responses were studied. The demographic profile is given in 
Table 1. Adolescents who participated in the study were in the age group 10-17 years. 437 were girls \& 795 were boys (male : female ratio $1.819: 1$ ). Responses to the various questions categorized for guiding action are given in Tables 2-6. For comparison the available results of the last i.e. '2007 Global School based Student Health Survey - India (CBSE) Survey', from the Public Use Codebook \& Factsheet have been given in the right-most column $[6,8]$.

\section{Nutritional status \& Dietary behaviors (Table 2)}

We categorized the findings Nutritional status classification into Nutritional status classification, Effort direction for weight, and Dietary habits.

The present study findings of overweight \& obese adolescents is $2.1 \%-10.3 \%$ and $0.8 \%-3.8 \%$ respectively across different adolescence age \& sex groups, similar to '2007 India (CBSE) GSHS' findings [6]. Underweight adolescents are $3.4 \%-11.6 \%$.

There is a sharp rise in number of girls making efforts to lose weight from early adolescence to middle adolescence ( $27.8 \%$ and $40.7 \%$ respectively). Boys trying to gain weight in early adolescence is $23.9 \%$ and $26.0 \%$ in the middle adolescence group. Also, there is a disparity between the nutritional status findings and the effort direction for weight.

Maximum number of the participants in the present study were eating fruits 2 times per day, and many more than 2 times per day. The vegetables consumption was also better than that of '2007 India (CBSE) GSHS' [8].

The trends in carbonated soft drinks intake reveals a sharp rise in males having these $\geq 1$ time per day from $36.3 \%$ in early adolescence to $61.8 \%$ in middle adolescence.

\section{Hygiene (Table 3)}

The findings are that hygienic practices are marginally short of $100 \%$, however cleanliness lacks more. These are better than the '2007 India (CBSE) GSHS' [6,8].

\section{Mental health (Table 4)}

We have categorized the characteristics/indicators in two groups, first being 'Feeling unsafe' and second 'Feelings and friendship'. Detailed findings of various aspects of and for mental health of our study are tabulated in Table 4. 
The finding of adolescents feeling lonely most of the time or always during the past 12 months in the present study (range $7.8 \%-12.2 \%$ ) is slightly higher than the finding of $8.7 \%$ of the ' 2007 India (CBSE) GSHS' [8].

The findings of the percentage of adolescents who were worried about something so that could not sleep at night most of the time/always during the past 12 months is higher than the '2007 India (CBSE) GSHS' (9.2\% - 18.7\% vis-a-vis 8\%) [8]. Also, there is sharp rise in number of girls feeling the same from early adolescence $9.8 \%$ to middle adolescence $18.7 \%$ in the present study.

The findings of 'feeling so sad or hopeless almost every day for two weeks or more in a row that stopped doing your usual activities' is high (range $27.2 \%$ - 28.4\%), and slightly higher than the '2007 India (CBSE) GSHS' (25.5\%) [8].

No close friends findings in our study is better (range 5.6\% - 8.1\%). The findings of students in the school being kind and helpful \& parents or guardians understanding problems and worries are satisfactory \& good.

\section{Physical activity (Table 5)}

The proportion of adolescents physically active for a total of at least 60 minutes per day on all 7 days during the past 7 days is higher (range $36.6 \%-51.1 \%$ ) than '2007 India (CBSE) GSHS' finding of 30.2\%.

Physical inactivity is trending towards the wrong side with $25.6 \%-38.6 \%$ of adolescents spending three or more hours per day during a typical or usual day sitting and watching television, playing computer games, talking with friends, or doing other sitting activities as compared to $23.2 \%$ in the '2007 India (CBSE) GSHS' [6]. This is rising from early to middle adolescence, and sharply in girls. The findings for girls in physical activity \& inactivity are worse as compared to boys in the present survey.

\section{Protective factors (Table 6)}

The present study findings are better in all these factors as compared to '2007 India (CBSE) GSHS' [6].

\section{Discussion}

Adolescent-health information within new global health initiatives has been advocated, with a recommendation that every country produce a regular report on the health of its adolescents [1].

\section{Nutritional status \& Dietary behaviors}


Nutritional status both lower and higher than ideal BMI has health effects. Proper health education early can address this with both short \& long term implications. The adolescents are image/body conscious and effort direction for weight can be put on right trajectory with teaching them about importance of BMI, and display of ideal values in schools, both in canteens and playgrounds.

The importance of fruits \& vegetables is well known. As per the Food guide pyramid the adequacy of vegetables \& fruits is defined as $4 / 5 \& 3 / 4$ servings per day for teenage girls/boys respectively. The latest recommendations based on MyPlate emphasize making half the plate vegetables and fruits [9]. Governmental advice on healthy diets is maximizing fruit and vegetable intakes [10]. Majority of the participants indicated that they were taught in school the benefits of eating more fruits and vegetables. This and the findings point towards reinforcing school teaching. Healthy habits will ensure strength in productive years of life rather than obesity with its attendant complications. Also, Beijing authorities have hit upon the novel idea of making teachers responsible for the weight of children in their class to curb rising juvenile obesity [11].

Teaching is for understanding \& results. The recommendations for healthy eating of fruits \& vegetables are in servings per day / half part of the plate, and the GSHS Questionnaire thus should be modified for proper assessment \& advanced for more accuracy. This harmonization can have significant implications in promoting fruits \& vegetables and impact health worldwide.

The trends in carbonated soft drinks needs to be suitably addressed. The producers have marketing strategies in place, often misleading the consumers. However the legislation of adding fruit juice and pulp in carbonated drinks, thoughtfully done by visionaries of progress for protecting \& promoting health, is a welcome step.

\section{Hygiene}

Un-cleanliness has realistic risks \& maintaining cleanliness has rewarding results. More efforts can ensure $100 \%$ hygienic practices \& facilities.

\section{Mental health}

Adolescents feeling lonely points to the need for more social interactions. Earlier data from available studies had suggested that loneliness is a painful and widespread problem among adolescents [12]. More recently it has been suggested that as the school is a setting in which adolescents are especially vulnerable to feelings of loneliness, school-based strategies could be particularly useful and widereaching [13].

The findings of the adolescents who were worried about something so that could not sleep at night most of the time/always points towards need for early anti-anxiety measures and health education 
for smooth transition across adolescent stages. The findings of 'feeling sad or hopeless', slightly higher than the '2007 India (CBSE) GSHS' also justify proactive steps. Mental health problems take a particularly big toll in the second decade [14].

Betterment of the aspects that students in the school being kind and helpful \& parents or guardians understanding problems and worries can contribute to the best state of mental health.

\section{Categorization of the characteristics/indicators into distinct sub-groups can contribute to focused approach for distinctive policies \& practical actions.}

\section{Physical activity}

The trends for physical activity/inactivity are alarming \& the findings of girls worrisome. Physical activity is desirable \& efforts in this direction need to be designed. For promoting physical activity amongst girls the GSHS Questionnaire can be advanced with questions for details of activity likings of the girls.

\section{Protective factors}

Adolescents engage in high-risk behaviors that cause significant morbidity and mortality [15]. Thus protective factors are important. The present study findings are better in all these factors as compared to '2007 India (CBSE) GSHS' [6], pointing that the efforts of the WHO and the Centers for Disease Control and Prevention $(C D C)$ of GSHS are bearing fruits and need to be sustained.

The strengths of the study are (i) Findings of early adolescence, as preventive and health promotion actions should be early (ii) Pointing domains showing deterioration across advancing physiological adolescence stages. The limitation of our study is that the participants were from one school, however they were from different parts of the country and frequent postings in the army make them study in different schools regularly.

\section{Conclusions}

On the basis of the findings \& analysis of these, a few suggestions for policies and promoting healthy practices have emanated. For the 'GSHS Questionnaire' suggestions are (i) Advancing for accuracy: harmonizing preaching and practice by modifying the questions on fruits \& vegetables consumption to how many servings servings/what part of plate rather than how many times per day. (ii) Advancing for avenues: For promoting physical activity amongst girls the GSHS Questionnaire should include questions for details of, including different types of physical activity likings of the girls.

Our findings of deterioration from early to middle adolescence points towards early action for prevention \& a healthy trajectory. The priorities for accomplishing the advancements of our Adolescents health, are (i) Popularizing the importance of \& display of values of ideal BMI (ii) Best hygienic practices attainment 
by sustaining \& strengthening the existing (iii) Betterment of mental health for smooth transition across different stages of adolescence \& being proactive for preventing worsening (iv) Early promotion of physical activity and prevention of inactivity, especially amongst adolescent girls (v) Strengthening \& sustaining protective factors.

\section{Key Messages}

\section{Key messages}

u Early \& sustained efforts needed for a healthy trajectory, especially in domains showing deterioration across advancing physiological adolescence stages

u Protective factors trending positively, pointing that the efforts of WHO and CDC of GSHS are bearing fruits and need to be sustained.

u GSHS questionnaire needs to be advanced for accuracy \& avenues

\section{Abbreviations}

GSHS: Global School-based Student Health Survey; yr(s): year(s); BMl: body mass index; SD: standard deviation

\section{Declarations}

\section{Ethics approval and consent to participate}

Command Hospital (Central Command), Lucknow, India Ethics Committee approved the study. Informed verbal consent from parent or legal guardian of all participants and informed verbal assent from participants of age more than 12 years was obtained. All were informed that this is a survey for developing better health programs, individual's responses will be kept confidential, and participation is voluntary. On the basis of this reasoning only verbal consent and assent was taken and the Institutional ethics committee approved this method.

\section{Consent to publish}

Not applicable.

\section{Availability of data and materials}

All data generated and analyzed during this study are included in this published article. 


\section{Competing interests}

The authors declare that they have no competing interests.

\section{Funding}

NIL

\section{Authors' Contributions}

SJ conceived and designed the work. SJ, AM, \& RKT did the data acquisition, analysis, and its interpretation. SJ, AM, \& RKT drafted the manuscript. SJ, AM, \& RKT are personally accountable for contributions, accuracy, \& integrity of the work. All authors have read and approved the final manuscript.

\section{Acknowledgements}

The authors would like to express their gratitude to the Army Public School- 1 Lucknow, India and its students for their support and participation.

\section{References}

1. Patton CG, Coffey C, Cappa c, et al. Health of the world's adolescents: a synthesis of internationally comparable data. The Lancet, 2012; 379 (9826): 1665 - 1675.

2. Global School-based Student Health Survey. Available from: www.who.int/chp/gshs/en/. Accessed Jun 2016.

3. 'Adolescents: health risks and solutions' Fact sheet. WHO,Updated May 2016; Available from www.who.int. Accessed Jun 2016.

4. Global School based Student Health Survey: Data User's Guide. Available from: www.who.int/chp/gshs/en/. Accessed Jun 2016.

5. Holland-Hall C \& Burstein GR. Adolescent Development. In: Kliegman RM, Stanton BF, Schor NF, St. Geme III JW, Behrman RE, editors. Nelson Textbook of Pediatrics 20th ed. Philadelphia: Elsevier; 2016. p 926-936.

6. Global School-based Student Health Survey India (CBSE) 2007 Fact Sheet. Available from: www.who.int/chp/gshs/en/. Accessed Jun 2016.

7. WHO Growth reference 5-19 years (BMI-for-age) - Interpretation of cut-offs. Available from: www.who.int/growthref/who2007. Accessed Jun 2016. 
8. 2007 Global School - based Student Health Survey results. India (CBSE) Survey, Public Use Codebook. Available from: www.who.int/chp/gshs/en/. Accessed Jun 2016.

9. Parks EP, Shaikhkhalil A, Groleau V, Wendel D, Stallings VA. Feeding Healthy Infants, Children, and Adolescents. In: Kliegman RM, Stanton BF, Schor NF, St. Geme III JW, Behrman RE, editors. Nelson Textbook of Pediatrics 20th ed. Philadelphia: Elsevier; 2016. p 286-295.e1.

10. Hanlon P, Byers M, Wilding JPH, \& Macdonald HM. Environmental and nutritional factors in disease. In: Walker BR, Colledge NR, Ralston SH, Penman ID, editors. Davidson's Principles and Practice of Medicine 22nd edition. Edinburgh: Churchill Livingstone; 2014. p 97 - 132.

11. Teachers Roped In For A Loss Cause? The Economic Times 2016 Jul 7; Editorial; 10 (col 1).

12. Moore DW, Schultz NR, Jr. Loneliness at Adolescence: Correlates, Attributions, and Coping. Journal of Youth and Adolescence, 1983; 12(2): $95 . \quad$ https://doi.org/10.1007/BF02088307

13. Martin KE, Wood LJ, Houghton S, Carroll A, Hattie J. 'I Don't have the Best Life': A Qualitative Exploration of Adolescent Loneliness. J Child Adolesc Behav, 2014; 2 (5): $\quad$ 169. doi:10.4172/23754494.1000169.

14. Health for the World's Adolescents: A second chance in the second decade. Available from www.who.int/adolescent/second-decade. Accessed: Jun 2016.

15. AAP COMMITTEE ON ADOLESCENCE. Achieving Quality Health Services for Adolescents. Pediatrics. 2016; 138(2): e20161347. doi: 10.1542/peds.2016-1347.

\section{Tables}

Table 1 Demographic profile

\begin{tabular}{|c|c|c|c|c|c|c|}
\hline \multirow{2}{*}{$\begin{array}{l}\text { Characteristic } \\
\text { Sex }\end{array}$} & \multicolumn{6}{|c|}{$\begin{array}{l}\text { Number of Adolescents } \\
n=1232\end{array}$} \\
\hline & \multicolumn{3}{|c|}{$\begin{array}{c}\text { Males } \\
\mathrm{n}=795\end{array}$} & \multicolumn{3}{|c|}{$\begin{array}{c}\text { Females } \\
\mathrm{n}=437 \\
\end{array}$} \\
\hline \multirow[t]{2}{*}{ Age } & \multicolumn{2}{|c|}{$\begin{array}{c}\text { Early adolescence } \\
\begin{array}{c}(10-13 \mathrm{yr}) \\
\mathrm{n}=760\end{array}\end{array}$} & \multicolumn{2}{|c|}{$\begin{array}{c}\text { Middle adolescence } \\
\qquad \begin{array}{c}(14-17 \mathrm{yr}) \\
\mathrm{n}=472\end{array}\end{array}$} & \multicolumn{2}{|c|}{$\begin{array}{c}\text { Late adolescence } \\
\begin{array}{c}(18-21 \mathrm{yr}) \\
\mathrm{n}=0\end{array}\end{array}$} \\
\hline & $\begin{array}{c}\text { Males } \\
\mathrm{n}=468\end{array}$ & $\begin{array}{c}\text { Females } \\
\mathrm{n}=292\end{array}$ & $\begin{array}{c}\text { Males } \\
\mathrm{n}=327\end{array}$ & $\begin{array}{c}\text { Females } \\
\mathrm{n}=145\end{array}$ & $\begin{array}{c}\text { Males } \\
\mathrm{n}=0\end{array}$ & $\begin{array}{c}\text { Females } \\
\mathrm{n}=0\end{array}$ \\
\hline Father's rank/occupation & \multicolumn{2}{|c|}{$\begin{array}{c}\text { Offrs } \\
\mathrm{n}=98 \\
\end{array}$} & $\begin{array}{l}\text { JCO's } \\
\mathrm{n}=231\end{array}$ & \multicolumn{2}{|c|}{$\begin{array}{l}\text { Other ranks } \\
\mathrm{n}=763\end{array}$} & $\begin{array}{l}\text { Civilian } \\
\mathrm{n}=140\end{array}$ \\
\hline Part of India & $\begin{array}{l}\text { North* } \\
\mathrm{n}=21\end{array}$ & $\begin{array}{l}\text { Sout } \\
\mathrm{n}=\end{array}$ & & & $\begin{array}{l}\text { est* } \\
=39\end{array}$ & $\begin{array}{l}\text { Central* } \\
\mathrm{n}=884\end{array}$ \\
\hline
\end{tabular}

* North: J \& K, Punjab, Haryana, Rajasthan, Himachal Pradesh, Uttarakhand, Chandigarh, Delhi

South: Tamil Nadu, Kerala, Karnataka, Andhra Pradesh, Telangana, Andaman \&

Nicobar, Puducherry, Lakshadweep

East: West Bengal, Orissa, Sikkim, Assam, Arunachal Pradesh, Mizoram, Manipur,

Meghalaya, Nagaland, Tripura

Page $11 / 16$ 
West: Gujarat, Maharashtra, Goa, Dadra \& Nagar Haveli, Daman \& Diu

Central: Madhya Pradesh, Chhattisgarh, Uttar Pradesh, Bihar, Jharkhand

Table 2 Nutritional status \& Dietary behaviors 


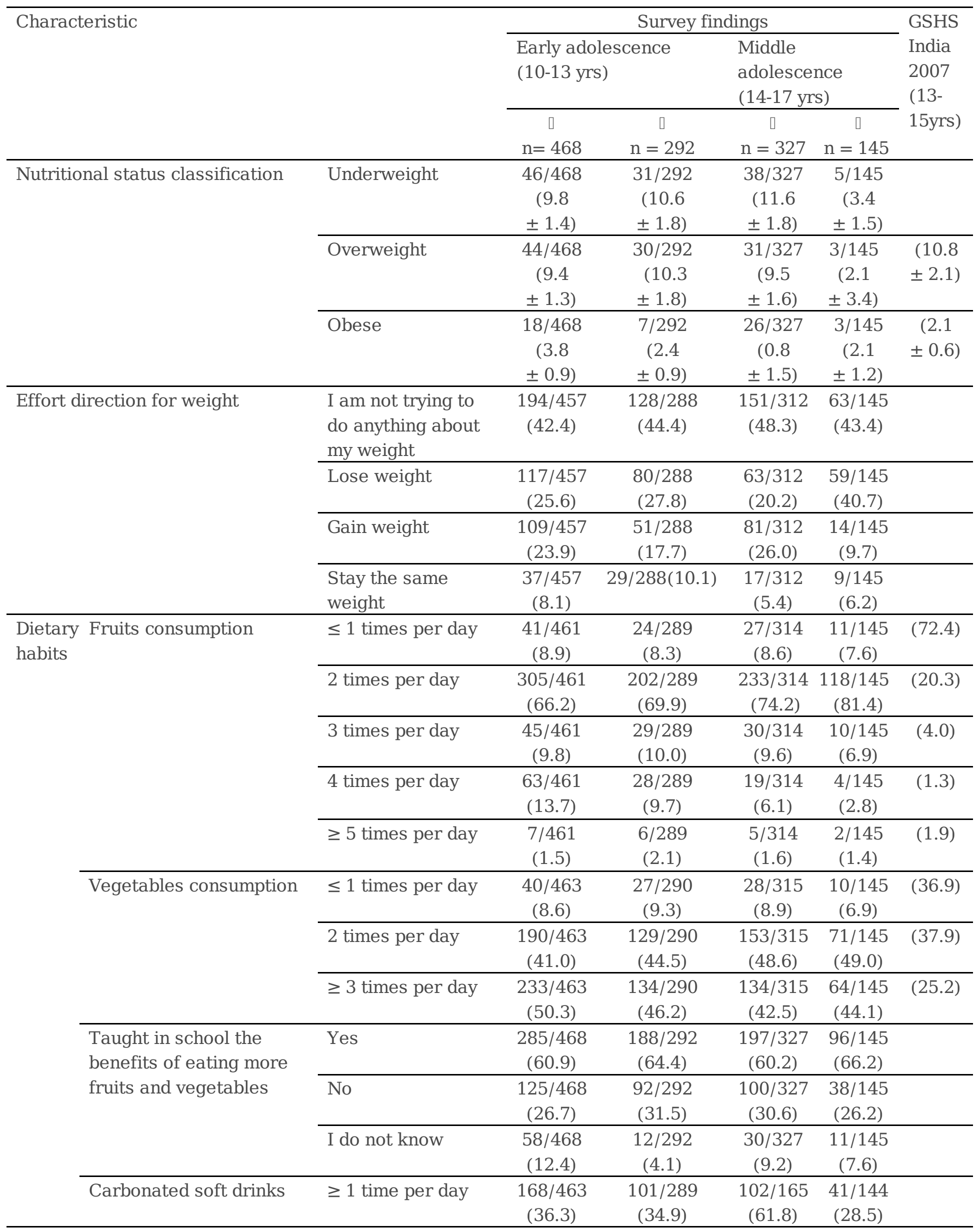


Figures are numbers/total responses \& data in brackets is percentage \pm Standard error

Table 3 Hygiene

\begin{tabular}{|c|c|c|c|c|c|c|}
\hline \multirow[t]{3}{*}{ Characteristic } & & \multicolumn{4}{|c|}{ Survey findings } & \multirow{3}{*}{$\begin{array}{l}\text { GSHS } \\
\text { India } \\
2007 \\
(13- \\
15 y r s)\end{array}$} \\
\hline & & \multicolumn{2}{|c|}{$\begin{array}{l}\text { Early adolescence } \\
(10-13 \mathrm{yr})\end{array}$} & \multicolumn{2}{|c|}{$\begin{array}{l}\text { Middle } \\
\text { adolescence } \\
(14-17 \mathrm{yr}) \\
\end{array}$} & \\
\hline & & $\mathrm{n}=468$ & $\mathrm{n}=292$ & $\mathrm{n}=327$ & $\mathrm{n}=145$ & \\
\hline \multirow[t]{4}{*}{ Care of teeth } & $\begin{array}{l}\text { Did not clean or brush my teeth during the } \\
\text { past } 30 \text { days }\end{array}$ & 0 & 0 & 0 & 0 & $(1.3)$ \\
\hline & $\begin{array}{l}\text { Cleaned or brushed their teeth }<1 \text { time per } \\
\text { day during the past } 30 \text { days }\end{array}$ & $\begin{array}{c}14 / 462 \\
(3.0) \\
\end{array}$ & $\begin{array}{c}11 / 291 \\
(3.8) \\
\end{array}$ & $\begin{array}{c}5 / 314 \\
(1.6) \\
\end{array}$ & 0 & $(3.3)$ \\
\hline & 1 time per day & $\begin{array}{c}88 / 462 \\
(19.1) \\
\end{array}$ & $\begin{array}{c}59 / 291 \\
(20.3) \\
\end{array}$ & $\begin{array}{c}103 / 314 \\
(32.8) \\
\end{array}$ & $\begin{array}{l}49 / 144 \\
(34.0) \\
\end{array}$ & $(40.4)$ \\
\hline & $\geq 2$ times per day & $\begin{array}{c}360 / 462 \\
(77.9)\end{array}$ & $\begin{array}{c}221 / 291 \\
(75.9)\end{array}$ & $\begin{array}{c}206 / 314 \\
(65.6)\end{array}$ & $\begin{array}{c}95 / 144 \\
(66)\end{array}$ & $(55.1)$ \\
\hline \multirow[t]{2}{*}{$\begin{array}{l}\text { Hand } \\
\text { Washing }\end{array}$} & $\begin{array}{l}\text { Never or rarely washed their hands before } \\
\text { eating during the past } 30 \text { days }\end{array}$ & $\begin{array}{c}14 / 462 \\
(3.0 \\
\pm 0.8) \\
\end{array}$ & $\begin{array}{c}5 / 291 \\
(1.7 \\
\pm 0.8) \\
\end{array}$ & $\begin{array}{c}8 / 315 \\
(2.5 \\
\pm 0.9) \\
\end{array}$ & $\begin{array}{c}5 / 144 \\
(3.5 \\
\pm 1.5) \\
\end{array}$ & $\begin{array}{r}(6.1 \\
\pm 1.1)\end{array}$ \\
\hline & $\begin{array}{l}\text { Never or rarely washed their hands after } \\
\text { using the toilet or latrine during the past } 30 \\
\text { days }\end{array}$ & $\begin{array}{l}12 / 464 \\
\quad(2.6 \\
\pm 0.7) \\
\end{array}$ & $\begin{array}{l}11 / 292 \\
(3.8 \\
\pm 1.1) \\
\end{array}$ & $\begin{array}{l}7 / 314 \\
(2.2 \\
\pm 0.8) \\
\end{array}$ & $\begin{array}{r}2 / 145 \\
(1.4 \\
\pm 1.0) \\
\end{array}$ & $\begin{array}{r}(3.3 \\
\pm 0.7)\end{array}$ \\
\hline \multirow[t]{2}{*}{$\begin{array}{l}\text { Toilet } \\
\text { facilities }\end{array}$} & $\begin{array}{l}\text { Separate toilets or latrines for boys and } \\
\text { girls at school? }\end{array}$ & $\begin{array}{c}428 / 464 \\
(92.2) \\
\end{array}$ & $\begin{array}{c}270 / 291 \\
(92.8) \\
\end{array}$ & $\begin{array}{c}303 / 314 \\
(96.5) \\
\end{array}$ & $\begin{array}{c}141 / 144 \\
(97.9) \\
\end{array}$ & \\
\hline & Clean toilets or latrines & $\begin{array}{c}382 / 457 \\
(83.6) \\
\end{array}$ & $\begin{array}{c}244 / 288 \\
(84.7) \\
\end{array}$ & $\begin{array}{c}264 / 313 \\
(84.4) \\
\end{array}$ & $\begin{array}{c}124 / 145 \\
(85.5) \\
\end{array}$ & \\
\hline $\begin{array}{l}\text { Clean water } \\
\text { for drinking }\end{array}$ & Source at school & $\begin{array}{c}394 / 458 \\
(86.0)\end{array}$ & $\begin{array}{c}251 / 289 \\
(86.9)\end{array}$ & $\begin{array}{c}270 / 314 \\
(86.0)\end{array}$ & $\begin{array}{c}128 / 144 \\
(88.9)\end{array}$ & \\
\hline
\end{tabular}

Figures are numbers/total responses \& data in brackets is percentage \pm Standard error

Table 4 Mental Health 


\begin{tabular}{|c|c|c|c|c|c|c|}
\hline \multirow[t]{3}{*}{ Characteristic } & & \multicolumn{4}{|c|}{$\begin{array}{c}\text { Survey findings } \\
\end{array}$} & \multirow{3}{*}{$\begin{array}{l}\text { GSHS } \\
\text { India } \\
2007 \\
(13- \\
15 y r s)\end{array}$} \\
\hline & & \multicolumn{2}{|c|}{$\begin{array}{l}\text { Early adolescence } \\
(10-13 \mathrm{yr})\end{array}$} & \multicolumn{2}{|c|}{$\begin{array}{l}\text { Middle adolescence } \\
(14-17 \mathrm{yr})\end{array}$} & \\
\hline & & $\mathrm{n}=468$ & $\begin{array}{c}\square \\
\mathrm{n}=292 \\
\end{array}$ & $\mathrm{n}=327$ & $\mathrm{n}=145$ & \\
\hline \multicolumn{7}{|l|}{ Feeling unsafe } \\
\hline \multirow{5}{*}{$\begin{array}{l}\text { Number of days, in the past } 30 \text { days, } \\
\text { did not go to school because felt } \\
\text { that would be unsafe at school or on } \\
\text { your way to or from school }\end{array}$} & 0 days & $\begin{array}{c}370 / 461 \\
(80.3)\end{array}$ & $\begin{array}{c}229 / 289 \\
(79.2)\end{array}$ & $\begin{array}{c}280 / 314 \\
(89.2)\end{array}$ & $\begin{array}{c}131 / 145 \\
(90.3)\end{array}$ & \\
\hline & 1 day & $\begin{array}{c}33 / 461 \\
(7.2) \\
\end{array}$ & $\begin{array}{c}30 / 289 \\
(10.4) \\
\end{array}$ & $\begin{array}{c}10 / 314 \\
(3.2) \\
\end{array}$ & $\begin{array}{c}8 / 145 \\
(5.5) \\
\end{array}$ & \\
\hline & 2 or 3 days & $\begin{array}{c}34 / 461 \\
(7.4) \\
\end{array}$ & $\begin{array}{c}16 / 289 \\
(5.5) \\
\end{array}$ & $\begin{array}{c}10 / 314 \\
(3.2) \\
\end{array}$ & $\begin{array}{l}5 / 145 \\
(3.5) \\
\end{array}$ & \\
\hline & 4 or 5 days & $\begin{array}{c}7 / 461 \\
(1.5)\end{array}$ & $\begin{array}{c}4 / 289 \\
(1.4)\end{array}$ & $\begin{array}{c}8 / 314 \\
(2.5)\end{array}$ & $\begin{array}{l}1 / 145 \\
(0.7)\end{array}$ & \\
\hline & $\geq 6$ days & $\begin{array}{c}18 / 461 \\
(3.9) \\
\end{array}$ & $\begin{array}{c}10 / 289 \\
(3.5) \\
\end{array}$ & $\begin{array}{c}6 / 314 \\
(1.9) \\
\end{array}$ & $\begin{array}{c}0 / 145 \\
(0)\end{array}$ & \\
\hline \multicolumn{7}{|l|}{ Feelings and friendships } \\
\hline \multirow[t]{3}{*}{$\begin{array}{l}\text { Felt lonely during the past } 12 \\
\text { months }\end{array}$} & Never & $\begin{array}{c}231 / 463 \\
(49.9) \\
\end{array}$ & $\begin{array}{c}134 / 286 \\
(46.9) \\
\end{array}$ & $\begin{array}{c}104 / 314 \\
(33.1) \\
\end{array}$ & $\begin{array}{c}36 / 145 \\
(24.8) \\
\end{array}$ & $(34.8)$ \\
\hline & $\begin{array}{l}\text { Rarely/ } \\
\text { sometimes }\end{array}$ & $\begin{array}{c}198 \\
(42.3) \\
\end{array}$ & $\begin{array}{c}117 / 286 \\
(40.9) \\
\end{array}$ & $\begin{array}{c}177 / 314 \\
(56.4) \\
\end{array}$ & $\begin{array}{c}92 / 145 \\
(63.5)\end{array}$ & $(56.5)$ \\
\hline & $\begin{array}{l}\text { Most of the } \\
\text { time/always }\end{array}$ & $\begin{array}{c}36 / 463 \\
(7.8) \\
\end{array}$ & $\begin{array}{c}35 / 286 \\
(12.2) \\
\end{array}$ & $\begin{array}{c}33 / 314 \\
(10.5) \\
\end{array}$ & $\begin{array}{c}17 / 145 \\
(11.7) \\
\end{array}$ & $(8.7)$ \\
\hline \multirow{3}{*}{$\begin{array}{l}\text { Worried about something that you } \\
\text { could not sleep at night during the } \\
\text { past } 12 \text { months }\end{array}$} & Never & $\begin{array}{c}215 / 458 \\
(46.9) \\
\end{array}$ & $\begin{array}{c}132 / 286 \\
(46.2) \\
\end{array}$ & $\begin{array}{c}135 / 314 \\
(43.0) \\
\end{array}$ & $\begin{array}{c}43 / 144 \\
(29.9) \\
\end{array}$ & $(35.0)$ \\
\hline & Rarely/sometimes & $\begin{array}{c}201 / 458 \\
(43.9) \\
\end{array}$ & $\begin{array}{c}126 / 286 \\
(44.1) \\
\end{array}$ & $\begin{array}{c}145 / 314 \\
(46.2) \\
\end{array}$ & $\begin{array}{l}74 / 144 \\
(51.4) \\
\end{array}$ & $(57.1)$ \\
\hline & $\begin{array}{l}\text { Most of the } \\
\text { time/always }\end{array}$ & $\begin{array}{c}42 / 458 \\
(9.2)\end{array}$ & $\begin{array}{c}28 / 286 \\
(9.8) \\
\end{array}$ & $\begin{array}{c}34 / 314 \\
(10.8)\end{array}$ & $\begin{array}{c}27 / 144 \\
(18.7)\end{array}$ & $(8.0)$ \\
\hline \multicolumn{2}{|c|}{$\begin{array}{l}\text { Feeling so sad or hopeless almost every day for two } \\
\text { weeks or more in a row that you stopped doing your } \\
\text { usual activities }\end{array}$} & $\begin{array}{c}131 / 461 \\
(28.4)\end{array}$ & $\begin{array}{l}78 / 287 \\
(27.2)\end{array}$ & $\begin{array}{c}88 / 314 \\
(28.0)\end{array}$ & $\begin{array}{l}41 / 145 \\
(28.3)\end{array}$ & $(25.5)$ \\
\hline \multicolumn{2}{|l|}{ No close friends } & $\begin{array}{c}36 / 444 \\
(8.1) \\
\end{array}$ & $\begin{array}{c}21 / 277 \\
(7.6) \\
\end{array}$ & $\begin{array}{c}25 / 312 \\
(8.0) \\
\end{array}$ & $\begin{array}{c}8 / 144 \\
(5.6) \\
\end{array}$ & $(10.3)$ \\
\hline \multirow{3}{*}{$\begin{array}{l}\text { How often did parents or } \\
\text { guardians understand his/her } \\
\text { problems and worries }\end{array}$} & Never & $\begin{array}{c}44 / 456 \\
(9.6) \\
\end{array}$ & $\begin{array}{c}48 / 290 \\
(16.6) \\
\end{array}$ & $\begin{array}{c}54 / 311 \\
(17.4) \\
\end{array}$ & $\begin{array}{c}24 / 144 \\
(16.7) \\
\end{array}$ & $(8.1)$ \\
\hline & Rarely/sometimes & $\begin{array}{c}71 / 456 \\
(15.6) \\
\end{array}$ & $\begin{array}{c}30 / 290 \\
(10.3) \\
\end{array}$ & $\begin{array}{c}54 / 311 \\
(17.4) \\
\end{array}$ & $\begin{array}{c}25 / 144 \\
(17.3)\end{array}$ & $(29.8)$ \\
\hline & $\begin{array}{l}\text { Most of the } \\
\text { times/always }\end{array}$ & $\begin{array}{c}341 / 456 \\
(74.8)\end{array}$ & $\begin{array}{c}212 / 290 \\
(73.1)\end{array}$ & $\begin{array}{c}203 / 311 \\
(65.3)\end{array}$ & $\begin{array}{c}95 / 144 \\
(66.0)\end{array}$ & $(62.0)$ \\
\hline
\end{tabular}

Figures are numbers/total responses \& data in brackets is percentage

Table 5 Physical Activity 


\begin{tabular}{|c|c|c|c|c|c|}
\hline \multirow[t]{3}{*}{ Characteristic } & \multicolumn{4}{|c|}{ Survey findings } & \multirow{3}{*}{$\begin{array}{l}\text { GSHS } \\
\text { India } \\
2007 \\
(13- \\
15 y r s)\end{array}$} \\
\hline & \multicolumn{2}{|c|}{$\begin{array}{l}\text { Early adolescence } \\
(10-13 \mathrm{yr})\end{array}$} & \multicolumn{2}{|c|}{$\begin{array}{l}\text { Middle } \\
\text { adolescence } \\
(14-17 \mathrm{yr}) \\
\end{array}$} & \\
\hline & $\mathrm{n}=468$ & $\mathrm{n}=292$ & $\mathrm{n}=327$ & $\begin{array}{c}\mathrm{n}= \\
145\end{array}$ & \\
\hline $\begin{array}{l}\text { Physically active for a total of at least } 60 \text { minutes per day on } \\
\text { all } 7 \text { days during the past } 7 \text { days }\end{array}$ & $\begin{array}{l}228 / 460 \\
(49.6 \\
\pm 2.3) \\
\end{array}$ & $\begin{array}{l}120 / 290 \\
(41.4 \\
\pm 2.9) \\
\end{array}$ & $\begin{array}{l}161 / 315 \\
(51.1 \\
\pm 2.8) \\
\end{array}$ & $\begin{array}{l}53 / 145 \\
(36.6 \\
\pm 4.0) \\
\end{array}$ & $\begin{array}{l}(30.2 \\
\pm 3)\end{array}$ \\
\hline $\begin{array}{l}\text { Spent three or more hours per day during a typical or usual } \\
\text { day sitting and watching television, playing computer games, } \\
\text { talking with friends, or doing other sitting activities }\end{array}$ & $\begin{array}{l}118 / 461 \\
(25.6 \\
\pm 2)\end{array}$ & $\begin{array}{l}79 / 291 \\
(27.1 \\
\pm 2.6)\end{array}$ & $\begin{array}{l}100 / 327 \\
(30.6 \\
\pm 2.5)\end{array}$ & $\begin{array}{c}56 / 145 \\
(38.6 \\
\pm 4.0)\end{array}$ & $\begin{array}{r}(23.2 \\
\pm 2.3)\end{array}$ \\
\hline
\end{tabular}

Figures are numbers/total responses $\&$ data in brackets is percentage \pm Standard error

Table 6 Protective Factors

\begin{tabular}{|c|c|c|c|c|c|}
\hline \multirow[t]{3}{*}{ Characteristic } & \multicolumn{4}{|c|}{ Survey findings } & \multirow{3}{*}{$\begin{array}{l}\text { GSHS } \\
\text { India } \\
2007 \\
\text { (13- } \\
15 y r s)\end{array}$} \\
\hline & \multicolumn{2}{|c|}{$\begin{array}{l}\text { Early } \\
\text { adolescence } \\
(10-13 \mathrm{yr}) \\
\end{array}$} & \multicolumn{2}{|c|}{$\begin{array}{l}\text { Middle } \\
\text { adolescence } \\
(14-17 \mathrm{yr}) \\
\end{array}$} & \\
\hline & $\mathrm{n}=468$ & $\begin{array}{c}\mathrm{n}= \\
292\end{array}$ & $\begin{array}{c}\mathrm{n}= \\
327\end{array}$ & $\begin{array}{c}\square \\
\mathrm{n}= \\
145\end{array}$ & \\
\hline $\begin{array}{l}\text { Students who missed classes or school without permission on } \\
\text { one or more days during the past } 30 \text { days }\end{array}$ & $\begin{array}{c}111 / 460 \\
(24.1 \\
\pm 2) \\
\end{array}$ & $\begin{array}{c}63 / 291 \\
(21.6 \\
\pm 2.4) \\
\end{array}$ & $\begin{array}{c}77 / 314 \\
(24.5 \\
\pm 2.4) \\
\end{array}$ & $\begin{array}{c}27 / 145 \\
(18.6 \\
\pm 3.2) \\
\end{array}$ & $\begin{array}{r}(26.8 \\
\pm 1.8)\end{array}$ \\
\hline $\begin{array}{l}\text { Students who reported that most of the students in their school } \\
\text { were never or rarely kind and helpful during the past } 30 \text { days }\end{array}$ & $\begin{array}{c}83 / 463 \\
(17.9 \\
\pm 1.8) \\
\end{array}$ & $\begin{array}{c}59 / 292 \\
(20.2 \\
\pm 2.3) \\
\end{array}$ & $\begin{array}{c}70 / 314 \\
(22.3 \\
\pm 2.3) \\
\end{array}$ & $\begin{array}{c}28 / 145 \\
(19.3 \\
\pm 3.3) \\
\end{array}$ & $\begin{aligned} & (41 \\
\pm & 4.6)\end{aligned}$ \\
\hline $\begin{array}{l}\text { Students whose parents or guardians never or rarely really } \\
\text { knew what they were doing with their free time during the past } \\
30 \text { days }\end{array}$ & $\begin{array}{l}44 / 460 \\
\quad(9.6 \\
\pm 1.4) \\
\end{array}$ & $\begin{array}{l}37 / 277 \\
(13.4 \\
\pm 2.0) \\
\end{array}$ & $\begin{array}{l}53 / 321 \\
(16.5 \\
\pm 2.1) \\
\end{array}$ & $\begin{array}{l}25 / 140 \\
(17.9 \\
\pm 3.2) \\
\end{array}$ & $\begin{array}{r}(27.9 \\
\pm 2.7)\end{array}$ \\
\hline
\end{tabular}

Figures are numbers/total responses \& data in brackets is percentage \pm Standard error 